\title{
Clinical profile and outcome of children with tuberculosis in a tertiary care hospital in Mumbai, India
}

\author{
*Noella Maria Delia Pereira ${ }^{1}$ \\ Sri Lanka Journal of Child Health, 2019; 48(4): 338-344
}

\begin{abstract}
Introduction: As children are usually infected by an adult with pulmonary tuberculosis (TB), childhood TB reflects transmission of Mycobacterium tuberculosis within a community
\end{abstract}

Objective: To study clinical profile and outcome of children with TB from 0 to 12 years of age in a tertiary care hospital in Mumbai, India.

Method: A prospective observational descriptive study of 30 children with TB was conducted over 18 months at a tertiary general hospital in Mumbai and followed up till recovery.

Results: Out of the 30 children with TB, 3 (10\%) were below the age of 1 year, $8(26.6 \%)$ were aged $1-5$ years and $19(63.3 \%)$ were above 5 years of age. Male to female ratio was $1: 1.3$. Extrapulmonary TB was more common $(63.3 \%)$ than pulmonary TB $(36.6 \%)$. Twenty $(66.6 \%)$ children had a history of previous adult contact with TB, 29 (96.6\%) were vaccinated with BCG and $10(33.3 \%)$ were malnourished. Common clinical features were cough (53.3\%), fever (46.6\%), weight loss (46.6\%) and lymphadenopathy $(33.3 \%)$. Anaemia and raised ESR were seen in $46.6 \%$ and $73.3 \%$ respectively. All 30 children were non-reactive for the HIV antibody test. Tuberculin sensitivity test was positive in 16 out of 30 children $(53.3 \%)$. Drug-resistant TB was seen in $2(6.6 \%)$ children. All 30 cases $(100 \%)$ recovered completely with their primary regimen.

Conclusions: In this study, extra-pulmonary TB was found in $63.3 \%$ of children. TST positivity $(>10 \mathrm{~mm})$ was found in only $53.3 \%$ of children with TB. Complete resolution of symptoms was seen in

${ }^{1} K$. J. Somaiya Medical College and Research
Centre, Mumbai, India
${ }^{*}$ Correspondence: noella_pereira@yahoo.com
iD) orcid.org/0000-0002-5818-0791 (Received on 10 March 2019: Accepted after revision on 26 April 2019)

The authors declare that there are no conflicts of interest

Personal funding was used for the project.

Open Access Article published under the Creative

Commons Attribution CC-BY (c) (i) all cases except the case of the Potts spine patient who had a residual spine deformity after completing treatment. A weight gain of $\geq 10 \%$ of body weight at diagnosis was seen at the end of 3 months in the age groups $<1$ year and $>5-12$ years.

DOI: http://dx.doi.org/10.4038/sljch.v48i4.8829

(Key words: Childhood tuberculosis, clinical profile, weight gain)

\section{Introduction}

As children are usually infected by an adult with pulmonary tuberculosis (TB), childhood TB is a reflection of the transmission of Mycobacterium tuberculosis within a community ${ }^{1-3}$. Mumbai is a city whose population has doubled since 1991 and where $41.3 \%$ of the residents live in the slums ${ }^{4}$. Rise in the urban population with consequent overcrowding and migration of families from rural areas to cities for work have led to increased poverty, malnutrition, morbidity and mortality rate of several diseases including $\mathrm{TB}^{5}$. Poverty has been a significant risk factor for TB in addition to severe malnutrition, illiteracy and a low socio-economic status ${ }^{6,7}$. Globally, TB incidence is decreasing by about $2 \%$ annually but this is not rapid enough to reach the 2020 milestones of the End TB strategy ${ }^{8}$.

Bacillus Calmette Guerin (BCG) vaccination has always been known to protect children from the severe forms of TB especially neuro-TB and disseminated $\mathrm{TB}^{9}$. Its efficacy varies from $75-86 \%$ for prevention of miliary TB and TB meningitis and is around $50 \%$ for pulmonary $\mathrm{TB}^{10}$. The estimated national coverage for BCG vaccination in India has increased from $74 \%$ to $91 \%$ between 1999 and $2013^{11}$. Poor immunisation coverage with BCG vaccine has been shown to play a significant role in the higher incidence and case fatality rate of neuro-TB ${ }^{12}$. The diagnosis of TB in childhood is most challenging as it is a pauci-bacillary disease thus relying on both clinical and radiological features for diagnosis and management ${ }^{13}$.

\section{Objectives}

To study the clinical profile and outcome of children with TB from 0 to 12 years of age in a tertiary care hospital in Mumbai, India. 


\section{Method}

This is a prospective observational descriptive study carried out in a tertiary care general hospital in Mumbai from $1^{\text {st }}$ February, 2017 to $31^{\text {st }}$ July, 2018, a period of 18 months. Ethical Approval was obtained from the institutional ethics committee. Informed consent was obtained from the parents. All children with TB $<12$ years old presenting to the out-patient department as well as those admitted in the ward were included in the study. Both pulmonary and extra-pulmonary TB patients as defined by WHO criteria ${ }^{13}$ were included in the study. Those treated outside the hospital or previously treated relapsed patients were excluded.

A detailed clinical history was obtained from the parents including a history of contact with TB and prior immunization with BCG. A thorough physical examination was carried out noting growth parameters such as weight, height, weight for height (aged 5 years or less) and body mass index aged 5 years or more). Malnutrition was defined as weight for height less than 2 standard deviations below the mean (' $z$ ' scores) for children aged 5 years or less ${ }^{14}$ and BMI less than -2SD for age for children above 5 years of age (' $z$ ' scores) $)^{15}$.

Investigations like haemogram, HIV by ELISA test, Mantoux tuberculin sensitivity test (5TU), sputum/gastric lavage for acid fast bacilli (AFB), sputum/gastric lavage for Xpert MTB/RIF and chest X-ray were carried out at the commencement of therapy. Specific investigations like body fluid analysis, CT scan/MRI, biopsy, fine needle aspiration cytology, tissue/fluid for Xpert MTB/RIF, culture and adenosine deaminase (ADA) levels were done whenever needed.

All patients were started on anti TB treatment according to the revised national TB programme guidelines ${ }^{16}$. Drug resistant TB was determined by Xpert MTB/RIF and drug sensitivity testing on positive TB culture tests at an RNTCP accredited laboratory. Anaemia was defined as haemoglobin $<11 \mathrm{~g} / \mathrm{dl}^{17}$. Elevated erythrocyte sedimentation rate (ESR) done at the end of 1 hour was defined as more than $20 \mathrm{~mm}$ by Westergren method.

Patients were followed up monthly for six months after starting therapy and their weight and height was recorded at each follow up visit. The primary outcome was the assessment of the clinical profile of these patients presenting with TB. The secondary outcome was to assess the weight gain in grams and percentage of weight gain of the body weight at diagnosis at the end of each month till six months after anti-tubercular treatment was started.
Statistical analysis

Characteristics of the children are described as numbers and percentages. For analysis of comparison of pulmonary TB and extra-pulmonary $\mathrm{TB}$, all characteristics were categorical in nature. Therefore, Fischer Exact test was used. $p<0.05$ was taken as statistically significant. For the average weight gain at the end of month of therapy in the different age groups, mean weight gain in grams of the children was calculated as well as the mean percentage of weight gain of the body weight at diagnosis was calculated in each of the age groups.

\section{Results}

During the study period $30(75 \%)$ children were treated for TB and followed up out of 40 patients. The characteristics of the children with TB are shown in Table 1.

Table 1

Characteristics of the children with $T B(n=30)$

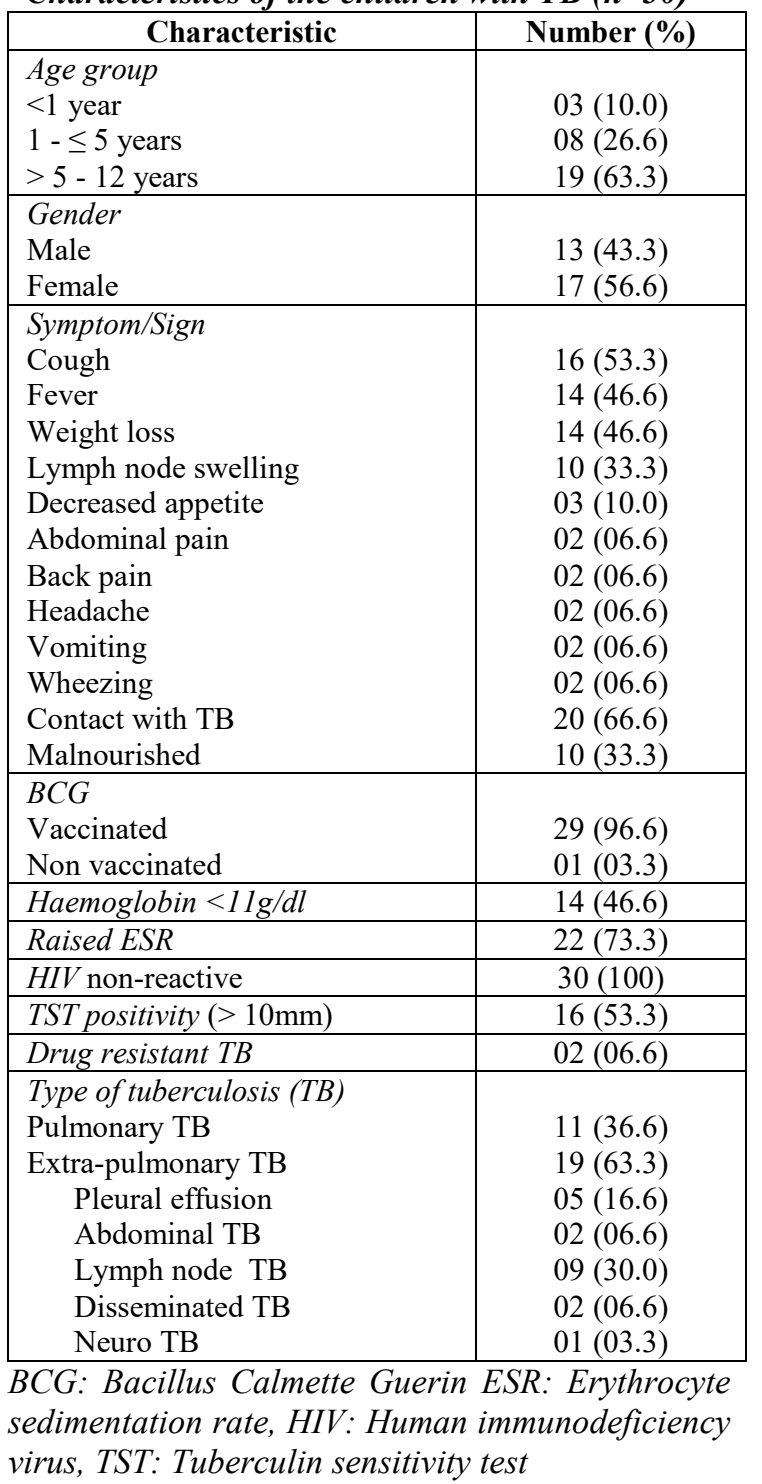


Two children presented with drug resistant TB and were both malnourished. One of them had disseminated TB (pleural effusion with Potts spine and paraspinal abscess) and the other child had pulmonary TB showing a cavitatory lesion on chest X-ray. Only one child was not vaccinated with BCG vaccine and she presented with disseminated TB (pleural effusion with paraspinal abscess). Mycobacterium tuberculosis (MTB) was isolated from the sputum/gastric lavage sample of the child with multi-drug resistant (MDR) pulmonary $\mathrm{TB}$ and from the pus drawn from the paraspinal abscess from the child with drug resistant TB with pleural effusion and Potts spine who was found to have Pre-XDR TB. All children completed their course of treatment and fully recovered. No child died during or after the course of treatment and none were lost to follow up. The child with drug resistant disseminated TB (pleural effusion with Potts spine and paraspinal abscess) mentioned above had a residual spine deformity at the end of treatment.

Comparison of children with pulmonary and extrapulmonary TB is shown in Table 2.

Table 2: Comparison of children with pulmonary and extra-pulmonary $\mathrm{TB}$

\begin{tabular}{|c|c|c|c|}
\hline Characteristic & $\begin{array}{c}\text { Pulmonary TB }(n=11) \\
\text { Number }(\%)\end{array}$ & $\begin{array}{c}\text { Extra-pulmonary TB }(n=10) \\
\text { Number }(\%)\end{array}$ & p value \\
\hline $\begin{array}{l}\text { Age group } \\
<1 \text { year } \\
1-\leq 5 \text { years } \\
>5-12 \text { years }\end{array}$ & $\begin{array}{l}02(18.1) \\
03(27.2) \\
06(54.5) \\
\end{array}$ & $\begin{array}{l}01(5.26) \\
05(26.3) \\
13(68.4) \\
\end{array}$ & $\begin{array}{c}0.536 \\
1 \\
0.695 \\
\end{array}$ \\
\hline $\begin{array}{l}\text { Gender } \\
\text { Male } \\
\text { Female } \\
\end{array}$ & $\begin{array}{l}08(72.7) \\
03(27.2)\end{array}$ & $\begin{array}{l}10(52.6) \\
09(47.3)\end{array}$ & 0.44 \\
\hline $\begin{array}{l}\text { Symptom/Sign } \\
\text { Cough } \\
\text { Fever } \\
\text { Weight loss } \\
\text { Lymph node swelling } \\
\text { Decreased appetite } \\
\text { Wheezing } \\
\text { Abdominal pain } \\
\text { Back pain } \\
\text { Headache } \\
\text { Vomiting } \\
\text { Contact with TB } \\
\text { Malnourished } \\
\end{array}$ & $\begin{aligned} & 09(81.8) \\
& 05(45.4) \\
& 07(63.6) \\
& 0(0.0) \\
& 02(18.1) \\
& 02(18.1) \\
& 0(0.0) \\
& 0(0.0) \\
& 0(0.0) \\
& 01(09.1) \\
& 10(90.9) \\
& 04(36.3) \\
&\end{aligned}$ & $\begin{array}{l}07(36.8) \\
09(47.3) \\
07(36.8) \\
10(52.6) \\
01(05.2) \\
0(0.0) \\
02(10.5) \\
02(10.5) \\
02(10.5) \\
01(05.2) \\
10(52.6) \\
06(31.5) \\
\end{array}$ & $\begin{array}{c}0.025 \\
1 \\
0.2568 \\
0.004 \\
0.5367 \\
0.1264 \\
0.5195 \\
0.5195 \\
0.5195 \\
1 \\
0.3927 \\
1 \\
\end{array}$ \\
\hline $\begin{array}{l}B C G \\
\text { Vaccinated } \\
\text { Non Vaccinated } \\
\end{array}$ & $\begin{array}{c}11(100) \\
0(0.0) \\
\end{array}$ & $\begin{array}{l}18(94.7) \\
01(05.2) \\
\end{array}$ & 1 \\
\hline Haemoglobin $<11 \mathrm{~g} / \mathrm{dl}$ & $06(54.5)$ & $08(42.1)$ & 0.7065 \\
\hline Raised ESR & $09(81.8)$ & $13(68.4)$ & 0.6722 \\
\hline TST positivity ( $>10 \mathrm{~mm})$ & $07(63.6)$ & $09(47.3)$ & 0.1461 \\
\hline Drug Resistant TB & $01(09.0)$ & $01(05.2)$ & 1 \\
\hline
\end{tabular}

TB: Tuberculosis, BCG: Bacillus Calmette Guerin ESR: Erythrocyte sedimentation rate, TST: Tuberculin sensitivity test

Cough was seen more significantly in children with pulmonary TB $(p=0.025)$ and lymph node swelling was seen more significantly in children with extrapulmonary TB $(\mathrm{p}=0.004)$ as seen in Table 2 .
For children $<1$ year of age, $1-\leq 5$ years and $>5$ 12 years, the average weight gain as well as the percentage of weight gain of body weight at diagnosis at the end of the each month after starting anti-tubercular treatment has been depicted in Table 3. 
Table 3: Average weight gain in grams and mean percentage of weight gain (of body weight at diagnosis) at the end of each month after starting anti-TB therapy

\begin{tabular}{|l|c|c|c|c|c|c|}
\hline \multirow{2}{*}{$\begin{array}{c}\text { End of } \\
\text { month }\end{array}$} & \multicolumn{2}{|c|}{$<\mathbf{1}$ year } & \multicolumn{2}{c|}{$\mathbf{1 - \leq 5}$ years } & \multicolumn{2}{c|}{$>$ 5-12 years } \\
\cline { 2 - 7 } & $\begin{array}{c}\text { Weight gain } \\
(\mathbf{g})\end{array}$ & $\begin{array}{c}\text { Weight gain } \\
(\mathbf{\%})\end{array}$ & $\begin{array}{c}\text { Weight gain } \\
\mathbf{( g )}\end{array}$ & $\begin{array}{c}\text { Weight gain } \\
(\mathbf{\%})\end{array}$ & $\begin{array}{c}\text { Weight gain } \\
(\mathbf{g})\end{array}$ & $\begin{array}{c}\text { Weight gain } \\
(\%)\end{array}$ \\
\hline 1 month & 450 & 9.02 & 385.75 & 3.015 & 1370 & 5.81 \\
\hline 2 month & 1113.33 & 24.58 & 636.25 & 5.359 & 2303.15 & 9.71 \\
\hline 3 month & 1640 & 38.7 & 860 & 7.53 & 2540 & 10.76 \\
\hline 4 months & 1886.66 & 45.7 & 1120 & 9.86 & 2944.21 & 12.38 \\
\hline 5 months & 2333.33 & 56.3 & 1367.5 & 12.11 & 3490.52 & 14.46 \\
\hline 6 months & 2586.66 & 60.8 & 1587.5 & 14.24 & 4004.21 & 16.91 \\
\hline
\end{tabular}

The weight gain seen in the children in the age group of $<1$ year is more than those seen in the other two age groups. The is probably due to more rapid weight gain seen normally in the first year of life as part of their normal growth and development.

Chest $\mathrm{x}$-ray findings in the 30 patients with childhood TB are shown in Table 4.

Table 4

Chest $x$ - ray findings in children with $T B(n=30)$

\begin{tabular}{|l|l|}
\hline \multicolumn{1}{|c|}{ Chest X ray findings } & \\
\hline Normal & $10(33.3)$ \\
\hline Perihilar lymphadenopathy & $07(23.3)$ \\
\hline Pleural effusion & $07(23.3)$ \\
\hline Segmental lesion(s) & $04(13.3)$ \\
\hline Calcification & $02(06.6)$ \\
\hline Bronchopneumonia & $01(03.3)$ \\
\hline Cavitation & $01(03.3)$ \\
\hline
\end{tabular}

Ten $(33.3 \%)$ children had a normal chest X-ray and those were children with extra-pulmonary TB (tuberculous lymphadenitis, abdominal tuberculosis, neuro-TB, and Potts spine). The term 'segmental lesion' refers to any radiographic opacity that clearly filled a lobe or a segment of a lobe ${ }^{18}$.

\section{Discussion}

The present study assessed the clinical profile and outcome of the children with TB. In this study, extra-pulmonary $\mathrm{TB}$ was found to be more common that pulmonary TB. This was similar to the findings seen in studies by Shrestha et $a l^{2}$ and Panigatti et $a l^{3}$. Extra-pulmonary TB is more common in children, superficial lymphadenitis being the most common form ${ }^{19}$. In the present study too, we found extra-pulmonary $\mathrm{TB}$ to be more common, superficial lymphadenitis being the most common form, typically involving the cervical lymph nodes.

The clinical findings in this study were similar to those found by Goyal et $a l^{20}$. Wheezing was seen as one of the presenting complaints in two children which was also seen in the study by Donald et $a l^{18}$.
Raised ESR was seen in $73.3 \%$ of the children with TB whilst TST positivity was seen in only $53.3 \%$. Failure to respond to tuberculin sensitivity test may result from poor nutrition, recent measles or measles immunisation, overwhelming tuberculous infection or an inherent lack of tuberculin hypersensitivity ${ }^{18}$. Therefore, a negative TST test does not rule out $\mathrm{TB}^{21}$.

The protective role of BCG vaccination is well known $^{22}$. However TB was seen in almost all children (96.6 percent) vaccinated with BCG. Hence it can be concluded that TB can be present in children vaccinated with $\mathrm{BCG}^{21}$. Absent $\mathrm{BCG}$ vaccination was associated with disseminated $\mathrm{TB}$ in this study as well as in the study done by Shrestha et $a l^{2}$.

The chest radiological findings seen mostly were perihilar lymphadenopathy and pleural effusion followed by segmental lesions, calcification, bronchopneumonia and cavitation. Segmental lesions typically involved the right lung. Similar findings were seen in studies by Donald et $a l^{18}$ and Shrestha et $a l^{2}$. Cavitation was seen in one child aged 12 years. In the study by Goyal et $a l^{20}$ older children $>5$ years were found to have cavitatory lesions which was also found in this study. Cavities are associated with a higher mycobacterial load and can therefore pose a transmission risk ${ }^{1}$.

Even though $66.6 \%$ children had a known adult contact with $\mathrm{TB}$, in a high burden TB setting like India, exposure from non-household sources in the community are important. Contact tracing of children of sputum-smear positive adults and chemoprophylaxis with isoniazid preventive therapy (IPT) can be an important strategy to prevent active $\mathrm{TB}^{23}$.

A favourable response to anti-tubercular treatment (weight gain and disappearance of symptoms and signs) are known features of probable $\mathrm{TB}^{24}$. In the present study, weight gain was seen in each of the age groups from $0-12$ years after starting antitubercular treatment. Marais et $a l^{25}$ have defined good clinical response as "complete symptom resolution and weight gain of $\geq 10 \%$ of body weight 
at diagnosis, within 3 months of starting anti-TB treatment". In the present study, complete resolution of symptoms was seen except in the case of the Potts spine patient who had a residual spine deformity after completing treatment. A weight gain of $\geq 10 \%$ of body weight at diagnosis was seen at the end of 3 months in the age groups $<1$ year and $>5-12$ years. However, in the age group $1-\leq 5$ years, weight gain seen at the end of 3 months was $<10 \%$ of the body weight at diagnosis. This could have been due to lack of proper nutrition and prolonged breastfeeding with improper weaning. Anaemia which was seen in $75 \%$ of the children in this age group could have also been contributory to poor weight gain.

The present study has a few limitations. The number of patients is small. Being a hospital based study, the type of patients seen may vary from those seen in the community. They may be far more critical due to delay in referral to the hospital for diagnosis and treatment. A high degree of suspicion is required to diagnose $\mathrm{TB}$ in a high prevalence setting and any pneumonia that does not respond to appropriate antibiotic therapy must be suspected of being tuberculous even if not confirmed bacteriologically. A positive TST along with clinical and radiological confirmation and a history of an adult contact with TB are diagnostic of TB in settings where the prevalence of malnutrition is high.

\section{Conclusions}

In this study, extra-pulmonary $\mathrm{TB}$ was found in $63.3 \%$ of children. TST positivity $(>10 \mathrm{~mm})$ was found in only $53.3 \%$ of children with TB. Complete resolution of symptoms was seen in all cases except the case of the Potts spine patient who had a residual spine deformity after completing treatment. A weight gain of $\geq 10 \%$ of body weight at diagnosis was seen at the end of 3 months in the age groups $<1$ year and $>5-12$ years.

\section{References}

1. Schaaf HS, Marais BJ, Whitelaw A, Hesseling AC, Eley B, Hussey GD, et al. Culture confirmed childhood tuberculosis in Cape Town, South Africa: a review of 596 cases. BMC Infectious Diseases 2007; 7:140.

https://doi.org/10.1186/1471-2334-7-140

PMid: 18047651 PMCid: PMC2225409

2. Shrestha S, Marahatta SB, Poudyal P, Shrestha SM. Clinical profile and outcome of childhood tuberculosis at Dhulikhel Hospital. Journal of. Nepal Paediatric. Society 2011; 31(1):11-6.
3. Panigatti P, Ratageri VH, Shivanand I, Madhu PK, Shepur TA. Profile and outcome of childhood tuberculosis treated with DOTS - An observational study. Indian Journal of Pediatrics 2014; 81(1):9 $-14$. https://doi.org/10.1007/s12098-013-11758

PMid: 23893370

4. World Population Review. Mumbai Population 2019. 2018. Available from: http:/worldpopulationreview.com/worldcities/mumbai-population/ [Accessed $11^{\text {th }}$ February 2019].

5. Zombini EV, de Almeida CHD, Silva FPCV, Yamada ES, Komatsu NK, de Figueiredo SM. Clinical epidemiological profile of tuberculosis in childhood and adolescence. Journal of Human Growth and Development 2013; 23(1):52-7. https://doi.org/10.7322/jhgd.50391

6. Seddon JA, Shingadia D. Epidemiology and disease burden of tuberculosis in children: a global perspective. Infection and Drug Resistance 2014; 7:153-65. PMid: 24971023 PMCid: PMC4069045

7. Janssens JP, Rieder HL. An ecological analysis of incidence of tuberculosis and per capita gross domestic product. European Respiratory Journal 2008; 32(5): 1415-6. https://doi.org/10.1183/09031936.0007870 8

PMid: 18978146

8. World Health Organization. 'Global Tuberculosis Report 2018'. WHO, Geneva, 2018. Available from: https://apps.who.int/iris/bitstream/handle/1 0665/274453/9789241565646-

eng.pdf?ua $=1$ [Accessed on $11^{\text {th }}$ February 2019].

9. Seth V, Kabra SK. Bacillus Calmette Guerin (BCG). In. Seth V and Kabra SK, editors. Essentials of Tuberculosis in Children. $4^{\text {th }}$ edition. New Delhi. Jaypee Brothers Medical Publishers; 2011:555588.

https://doi.org/10.5005/jp/books/11309_38

10. Advisory Committee on Vaccine \& Immunization Practices (ACVIP). Bacillus Calmetter Guerin (BCG) Vaccine. In. Vashishtha VM, Choudhury P, Bansal CP, 
Yewale VN, Agarwal R, editors. IAP Guidebook on Immunization 2013-14 Gwalior, National Publishing House, Indian Academy of Pediatrics;2014:111114.

11. Bhatnagar P, Gupta S, Kumar R, Halder P, Sethi R, Bahl S. Estimation of child vaccination at state and national levels in India. Bulletin of the World Health Organisation. 2016; 94(10):728-34. https://doi.org/10.2471/BLT.15.167593 PMid: 27843162 PMCid: PMC5043206

12. Gupta R, Garg A, Venkateshwar V, Kanitkar M. Spectrum of childhood tuberculosis in BCG vaccinated and unvaccinated children. Medical Journal Armed Forces India. 2009; 65:305-7. https://doi.org/10.1016/S03771237(09)800 88-9

13. World Health Organization. Definitions and reporting framework for tuberculosis - 2013 revision (updated December 2014). WHO, Geneva, 2013. Available from: https://apps.who.int/iris/bitstream/handle/1 0665/79199/9789241505345 eng.pdf;jses sionid=C55C0B13E5AB190B1B8037D69 $59 B 4 E A 4$ ? sequence $=1$ [Accessed on $13^{\text {th }}$ February 2019].

14. World Health Organization. WHO Child Growth Standards. Length/height-for-age, weight-for-age, weight-for-length, weightfor-height and body mass index-for-age. Methods and development. WHO, Geneva, 2006. Available from:

https://www.who.int/childgrowth/standard s/Technical_report.pdf?ua $=1$ [Accessed on $17^{\text {th }}$ February 2019]

15. .De Onis $\mathrm{M}$, Onyango AW, Borghi E, Siyam A, Nishida C, Siekmann J. Development of a WHO growth reference for school - aged children and adolescents. Bulletin of the World Health Organisation. 2007; 85(9):660-7.

https://doi.org/10.2471/BLT.07.043497

PMCid: PMC2636412

16. Central TB Division, Directorate General of Health Services, Ministry of Health and Family Welfare, New Delhi, India. Revised National TB Control Programme. Technical and Operational Guidelines for Tuberculosis Control in India. 2016.. Available from: https://tbcindia.gov.in/index 1.php?lang=1

\&level $=2 \&$ sublinkid $=4573 \&$ lid $=3177$

[Accessed on $13^{\text {th }}$ February 2019].

17. World Health Organization. Haemoglobin for concentrations for the diagnosis of anaemia and assessment of severity. Vitamin and Mineral Nutrition Information System. 2011; 1-6. Available from:

https:/www.who.int/vmnis/indicators/hae moglobin.pdf [Accessed on 3rd March 2019].

18. Donald PR, Ball JB, Burger PJ. Bacteriologically confirmed pulmonary tuberculosis in childhood. Clinical and radiological features. South African Medical Journal 1985; 67(15):588-90.

19. Shingadia D, Novelli V. Diagnosis and treatment of tuberculosis in children. Lancet Infectious Diseases 2003; 3(10):624-32.

https://doi.org/10.1016/S14733099(03)007 71-0

20. Goyal A, Shah I, Patankar N, Chilkar S. Clinical profile of children with pulmonary tuberculosis. Clinical Epidemiology and Global Health.2014; 2(1):24-7.

https://doi.org/10.1016/j.cegh.2014.01.003

21. Nanavath K, Karimunnisa S. Clinical profile of paediatric cases with tuberculosis. IOSR Journal of Dental and Medical Sciences 2017; 16(9):06-08.

22. Centers for Disease Control and Prevention. The Role of BCG Vaccine in the Prevention and Control of Tuberculosis in the United States. A Joint Statement by the Advisory Council for the Elimination of Tuberculosis and the Advisory Committee on Immunization Practices. MMWR Recomm Rep. 1996; 45(RR-4):118. [Online]. Available online from: https://www.cdc.gov/mmwr/pdf/rr/rr4504. pdf [Accessed on 23rd February 2019].

23. Said K, Hella J, Ruzegea M, Solanki R, Chiryamkubi M, Mhimbira F, Ritz N, Schindler C, Mandalakas AM, Manji K, Tanner M, Utzinger J, Fenner L. Immunologic - Based Diagnosis of Latent Tuberculosis among Children less than 5 years of age exposed and unexposed to tuberculosis in Tanzania: Implications for 
Tuberculosis Infection Screening. Pediatr Infect Dis J. 2018. [Epub ahead of print].

24. Osborne CM. The challenge of diagnosing childhood tuberculosis in a developing country. Archives of Disease in Childhood.1995; 72(4):369-74.

https://doi.org/10.1136/adc.72.4.369

PMid: 7763076 PMCid: PMC1511255
25. Marais BJ, Gie RP, Hesseling AC, Schaaf $\mathrm{S}$, Lombard C, Enarson DA, et al. A refined symptom -based approach to diagnose pulmonary tuberculosis in children. Pediatrics 2006; 118(5):e13509.

https://doi.org/10.1542/peds.2006-0519

PMid: 17079536 